\title{
KEKERASAN SEKSUAL TERHADAP PEREMPUAN PERSPEKTIF FIKIH KLASIK
}

\author{
Suwarjin \\ Dosen Fakultas Syariah \\ Email: siajina@yahoo.com
}

\begin{abstract}
Books circulating widely in Indonesia and viewed as authoritative regarding sexual issues generally place women as subordinate men. Men are leaders and rulers of women, while women as guided must obey the husband's command. The piety of a wife is measured by how far the devotion of her body soul to her husband. The virtuous wife is the one who never demands his rights from the husband, does not go out and give charity without the husband's permission, does not raise his eyes and voice in the presence of the husband, does not require knowledge except with the permission of the husband, and does not worship the sunna without the blessing of the husband. If the husband does not grant his rights, then he must give up with sincerity to be saved from the terrible threat of God's punishment. Related to intimate relationships, women are positioned as sex objects, not subjects. He should not delay the sexual desire of the husband, let alone reject it. Such positions have an adverse effect on the wife. Wives often experience sexual violence and neglected their sexual rights. The underlying perspective of husband-wife sexual relationships in the jurisprudential books circulating in Indonesia is generally still classic and emphasizes only the power of men against women in the family. Such perspectives are no longer appropriate to the present condition, in which sexual problems are seen as a common right that should be practiced fairly between husband and wife. Allegedly there has been a distortion of understanding of husband-wife sexual relationships that need to be straightened out, in order to avoid the impression, Islam legalize sexual violence in women.
\end{abstract}

Keywords: sexual violence, classic book.

Abstrak: Kitab-kitab yang beredar luas di Indonesia dan dipandang otoritatif terkait masalah seksual umumnya menempatkan wanita sebagai subordinat laki-laki. Laki-laki adalah pemimpin sekaligus penguasa perempuan, sedang perempuan sebagai yang terpimpin harus patuh pada perintah suami. Kesalehan seorang istri diukur melalui seberapa jauh pengabdian jiwa raganya pada suami. Istri yang saleh adalah yang tidak pernah menuntut hak-haknya dari suami, tidak keluar rumah dan bersedekah tanpa izin suami, tidak mengangkat pandangan dan suara di hadapan suami, tidak menuntut ilmu kecuali dengan izin suami, serta tidak beribadah sunnah tanpa restu suami. Seandainya suami tidak memberikan hak-haknya, maka ia harus merelakannya dengan penuh keikhlasan agar selamat dari ancaman siksa Allah yang amat pedih. Terkait hubungan intim, perempuan diposisikan sebagai obyek seks, bukan subyek. Ia tidak boleh menunda hasrat seksual sang suami, apalagi menolaknya. Pemposisian seperti ini menimbulkan dampak yang merugikan istri. Istri sering mengalami kekerasan seksual dan diabaikan hak-hak seksualnya. Perspektif yang mendasari hubungan seksual suami-istri dalam kitab-kitab fikih yang beredar di Indonesia umumnya masih bercorak klasik dan hanya menekankan kekuasaan laki-laki terhadap perempuan dalam keluarga. Perspektif seperti ini tidak sesuai lagi dengan kondisi kekinian, di mana masalah seksual dipandang sebagai hak bersama yang harus dipraktikkan secara adil antara suami dan istri. Di duga telah terjadi distorsi pemahaman terhadap hubungan seksual suami-istri yang perlu diluruskan, agar tidak timbul kesan, Islam melegalkan kekerasan seksual pada perempuan.

Kata Kunci: kekerasan seksual, kitab klasik.

\section{Pendahuluan}

Perbincangan tentang seks bisa jadi merupakan perbincangan paling menarik orang dewasa. Sejak dulu orang membicarakan persoalan seks dalam berbagai konteks dan kepentingan, melalui seminar, saresehan, halaqah, majelis ta'lim atau lainnya.
Media cetak dan elektronik juga tak ketinggalan memuat dan menayangkan berita terkait hal yang satu ini. ia diperbincangkan oleh semua manusia dalam berbagai strata sosialnya, dari buruh, majikan, penguasa, rakyat biasa, politisi, dari office boy hingga komisaris perusahaan raksasa. Ini dikarenakan seks 
Suwarjin | Kekerasan Seksual Terhadap Perempuan

merupakan kebutuhan semua manusia dewasa. Seks juga sering menimbulkan persoalan di tengah masyarakat, dari masyarakat paling primitif hingga paling modern. Seks bisa merekatkan suatu hubungan, tapi juga bisa menjadi faktor yang memporakporandakan hubungan.

Dalam masyarakat Islam Indonesia, persoalan hubungan seks suami-istri masih terus didiskusikan. Arus utama (maenstream) pemahaman tentang masalah ini didominasi oleh anggapan bahwa seks adalah hak suami yang harus ditunaikan oleh istri. Istri tidak punya pilihan lain selain menuruti hasrat seksual suaminya. Jangankan menolak, menunda keinginan suami untuk menikmati tubuhnya pun merupakan dosa besar baginya. ${ }^{1}$ Bahkan ia terancam tidak dapat masuk surga karenanya. Seandainya, istri sedang menunggang kuda atau unta, lalu suami menginginkan dirinya, ia pun harus menurutinya. $^{2}$ Kitab-kitab klasik yang beredar di Indonesia menggambarkan sedemikian detil kewajiban perempuan mematuhi suami dalam masalah ini. kitab-kitab tersebut, meskipun sebagiannya ditulis pada abad-abad modern, tetapi secara substansi masih mengikuti arus pemahaman yang berkembang pada periode Islam klasik, karena itu, kitabkitab ini digolongkan kedalam kitab klasik.

Pemahaman seperti ini nampak bertentangan dengan fakta sejarah yang dipraktikkan oleh Nabi, para sahabat dan as-salaf ash-shalih. Dalam hadis Nabi terdapat pernyataan yang membuktikan bahwa hak seksual istri setara dengan hak seksual suami. Diriwayatkan bahwa Jabir bin Abdillah yang baru saja menikahi seorang janda, menemui Nabi. Nabi lalu berkata kepadanya:

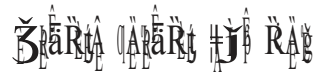

(kenapa kamu tidak menikahi perawan, supaya kamu bisa mencumbuinya dan ia mencumbuimu?). ${ }^{3}$ Hadis ini memberi petunjuk bahwa istri mempunyai hak untuk menikmati keindahan seksual bersama suami, sebagaimana suami mempunyai hak yang sama terhadap dirinya. Ini berart suami berkewajiban melayani kepuasan seks sang istri, dan tidak melakukan sesuatu yang dapat menghilangkannya.

Pada hadis yang lain, Nabi menegaskan perlunya berlaku baik dan lemah lembut dalam menggauli istri. Salah satu kelembutan yang harus di-

'Asy-Syekh al-Imam Abu Muhammad Maulana at-Tihami, Syarh Qurrah al-'Uyun, Surabaya: Dar al-'Ilm, t.th.), h. 20.

${ }^{2}$ Syekh Nawawi al-Bantani, Syarh Uqud al-Lujain fi Bayan Huquq azZaujain, (t.tp: tp, t.th.),h. 10

${ }^{3}$ Muhammad bin Isma'il bin Ibrahim bin al-Mughirah al-Bukhari, Shahih al-Bukhari, (t.t.: Dar Thauq an-Najah, 1422 H.) juz 7, h. 39. tunjukkan suami adalah dengan cara melontarkan pujian kepada istri, mencumbuinya, memesrainya dan memberi ciuman kehangatan. Dengan pemanasan seperti ini, istri akan mudah terkondisi untuk mencapai puncak orgasme. Suami tidak dibenarkan menggauli istri tanpa ada pemanasan. Ini berarti bahwa suami tidak boleh memaksakan kehendaknya melakukan hubungan seksual. Suami harus berusaha mempersiapkan kondisi psikis istrinya agar ia siap melakukan hubungan seksual, bisa melalui rangsangan, kata-kata pujian, ciuman dan cumbuan atau lainnya.

Kalau demikian halnya, berarti telah terjadi distorsi pemahaman tentang hak-hak seksual istri dalam kitab-kitab fikih klasik. Penggambaran secara timpang dalam kitab-kitab tersebut merupakan 'kesan' yang kurang tepat dari sebagian ulama dalam menjelaskan hubungan seksual suami-istri. Ketimpangan ini bukan bersumber dari teks-teks suci, melainkan lebih pada konstruksi budaya yang menempatkan perempuan sebagai subordinat laki-laki, ${ }^{4}$ termasuk dalam hubungan seksual. Pemahaman yang demikian bertentangan dengan semangat hukum Islam yang menjunjung tinggi keadilan dan kerahmatan bagi semesta. ${ }^{5}$ Karenanya diperlukan pembaruan pemahaman terhadap teks-teks yang dijadikan dasar legitimasi pemposisian istri (perempuan) di bawah laki-laki.

\section{Pembahasan}

\section{Kekerasan Seksual di Indonesia}

Seperti diketahui, salah satu fungsi keluarga adalah fungsi reproduksi dan fungsi rekreasi. Fungsi reproduksi berarti bahwa reproduksi (at-tanasul, at-tawalud) yang legal hanya dimungkinkan apabila hubungan tersebut diikat dalam perkawinan yang sah. Sedang fungsi rekreasi menekankan aspek eksotisme seks yang mampu mengurai beban dan hambatan psikologis pasangan suami-istri. Pada aspek eksotisme seks, Syekh Nawawi Banten menjelaskan bahwa setiap pasangan (atau lebih tepatnya suami) memiliki hak untuk mengeksplorasi gaya/fantasi seksual yang memungkinkan suami mencapai orgasme yang diinginkan. ${ }^{6}$ Bahkan, jikalau istri sedang duduk di atas punggung unta, lalu suaminya menginginkan tubuhnya, ia tidak boleh menolaknya. ${ }^{7}$ Ia akan menjadi wanita yang sangat

${ }^{4}$ Asghar Ali Engineer, Pembebasan Perempuan, terj. Agus Nuryatno, (Yogyakarta: LkiS, 2007), h. 65.

'Ibn Qayyim al-Jauziyah, I'am al-Muwaqqi'n 'an Rabb al-'Alamin, http// www.al-islam.com, jilid 3, h. 3.

${ }^{6}$ Syekh Nawawi Banten, Marah Labid li Kasyf Ma'na al-Qur'an al-Majid, (Bandung: Syirkah al-Ma'arif, t.th.) juz 1, 77.

${ }^{7}$ Syekh Nawawi Banten, Syarh Uqud al-Lujain ii Bayan Uquq az-Zaujain, (t.tp: tp, t.th.), 14. 
Suwarjin I Kekerasan Seksual Terhadap Perempuan

beruntung kalau dapat memberikan kepuasan seksual kepada suaminya. Untuk memperkuat pandangannya ini ia merujuk pada hadis riwayat Imam Tirmizi sebagai dalilnya. ${ }^{8}$ Keridhaan suami ini menurutnya sangat penting, karena menjadi syarat bagi keridhaan Allah. ${ }^{9}$ Namun, eksotisme seks dengan berbagai ragam gaya dan sensasi orgasme tersebut harus hanya bersumber dari vagina, bukan dari anal seks yang menurutnya termasuk dalam kelompok dosa besar. ${ }^{10}$ Pendapat Syekh Nawawi Banten ini sama dengan pendapatnya Asy-Syekh al-Imam Abu Muhammad dalam syarh Qurrah al-'Uyun. Ia berpendapat bahwa suami boleh mendatangi istrinya dari arah belakang, selama obyeknya tetap vagina. Ia menyitir hadis Nabi sebagai dasar argumennya:

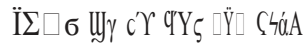

$$
\begin{aligned}
& \alpha^{\prime} \mathrm{Aм}
\end{aligned}
$$

(adalah boleh melakukan hal tersebut, selama obyeknya tetap lobang yang satu (vagina). ${ }^{11}$

Kewajiban istri melayani hasrat seksual ini merupakan kewajiban agama yang bersifat segera yang dalam istilah Usuliyyun disebut wajib aala al-faur, tidak boleh ditunda dengan alasan apapun. Ia tidak boleh membuat suami menunggu untuk menikmati kemolekan tubuhnya. ${ }^{12}$ Sebab, segenap kemolekan tubuhnya merupakan hak suami untuk menikmatinya. Menunda-nunda hasrat seksual suami adalah bagian dari perbuatan dosa yang tidak boleh dilakukan istri. Ia berhujjah dengan sebuah hadis Nabi:

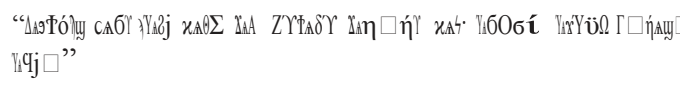

(siapa saja wanita yang diajak suaminya ke tempat tidur lalu ia menunda-nunda hingga suaminya tertidur, maka ia terlaknat). ${ }^{13}$

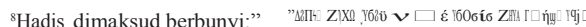
(Perempuan manapun yang berada pada waktu malam dalam keadaan diridhai suaminya, pasti masuk surga)

${ }^{9}$ Syekh Nawawi Banten, Syara Uqud al-Lujain, 16.

${ }^{10}$ Syekh Nawawi Banten, Marah Labid, juz 1, 77. Pandangan ini didasarkan pada surat al-Baqarah ayat 223. Kata: 'harsun' pada ayat tersebut ditafsirkan dengan kata: 'furuj' (vagina). Atas dasar ini ia berpendapat bahwa hubungan seks antara suami istri hanya boleh dilakukan pada vagina. Mengenai tekniknya diserahkan pada masing-masing pasangan, apakah mau dari arah depan ataupun belakang, tidak menjadi masalah. Ayat ini diturunkan sebagai penolakan terhadap keyakinan orang Yahudi bahwa barang siapa mendatangi istrinya dari arah belakang, maka anak yang dilahirkan akan juling matanya. Mereka menyangka ketentuan ini terdapat dalam Taurat.

${ }^{11}$ Asy-Syekh al-Imam Abu Muhammad, Qurrah al-'Uyun Berbulan Madu Menurut Ajaran Rasulullah, terj. Asy’ari Mahmud, (t.t: t.p, t.th.), 107108.

$$
\begin{aligned}
& { }^{12} \text { Ibid., h. } 20 . \\
& { }^{13} \text { Ibid., } 12 .
\end{aligned}
$$

Hak suami untuk mengeksploitasi fantasi seksual terhadap istri ini menimbulkan kesan bahwa dalam masalah seks istri tidak lebih berfungsi sebagai obyek, bukan sebagai subyek. Dalam Syarh 'Uqud al-Lujain, ada penekanan bahwa seks merupakan hak suami dan kewajiban istri adalah menuruti keinginan dan hasrat seksual suami. Ia sama sekali tidak mempertimbangkan kondisi fisik dan psikis istri serta kepuasan seksual istri. ${ }^{14}$ Kewajiban istri melayani suami ini dijustifikasi melalui ayat dan Hadis Nabi. ${ }^{15}$ Menurut Munir Mulkhan, kekerasan seksual yang dialami perempuan tidak dapat dilepaskan dari tiga persoalan. Pertama, tradisi Islam dalam fikih yang menempatkan perempuan sebagai pelayan kebutuhan seksual pria dan pembangkit birahi seksual. Kedua, kecenderungan konsumerisme tubuh perempuan dalam peradaban industri modern. Ketiga, tradisi lokal, khususnya Jawa yang menempatkan perempuan sebagai penumpang kamukten (kemuliaan) pria. ${ }^{16}$

Pelabelan (stereotype) bahwa istri adalah pelayan seksual suami sering menimbulkan kekerasan seksual dalam rumah tangga. Kekerasan seksual bisa mengambil banyak bentuk, seperti anal sex, oral sex, seks pada saat menstruasi, sadomasokisme, dan sejumlah tindakan yang membuat istri tidak merasa nyaman saat melakukan hubungan seksual. Padahal, hubungan seksual tersebut mestinya dinikmati oleh kedua belah pihak. Istri juga berhak menikmati keindahan seks sebagaimana laki-laki. Ia juga berhak menentukan bagaimana kepuasan seks itu menurut seleranya, selama tidak keluar dari koridor yang ada. Namun pada kenyataannya, tidak banyak perempuan yang mampu melakukannya. Di perkotaan, di mana perempuan memperoleh pendidikan lebih baik, lebih cenderung memperoleh hak menikmati hubungan seksual dengan suami. Tetapi di perdesaan, di mana budaya patriarki masih dipegang teguh, perempuan sulit memperoleh haknya menentukan kepuasan seksualnya sendiri.

Saat ini persoalan kekerasan seksual menjadi sangat rumit dan problematik pasca lahirnya un-

${ }^{14}$ Ibid., 14

${ }^{15}$ Ayat dimaksud antara lain adalah surat an-Nisa' ayat 34 yang menekankan ketaatan kepada suami. Sedang hadis yang dijadikan dasar argumentasinya antara lain adalah hadis tentang kewajiban istri memenuhi ajakan suami meskipun ia sedang berada di atas punggung unta, hadis tentang kutukan bagi istri yang tidak mau melayani hasrat seks suaminya, hadis tentang laknat bagi perempuan yang menunda memenuhi panggilan suami ke tempat tidur, dan hadis tentang keridhaan Allah atas istri yang dengan tulus memenuhi ajakan suaminya ke tempat tidur, yang disebutkan dalam kitab Syara Uqud al-Lujain.

${ }^{16}$ Abdul Munir Mulkhan, Perspektif Sosiologis Kekerasan Fikih terhadap Perempuan, dalam, S. Edi Santoso, Islam dan Konstruksi Seksualitas, (Yogyakarta: Pustaka Pelajar, 2002), 201. 
Suwarjin | Kekerasan Seksual Terhadap Perempuan

dang-undang nomor 23 tahun 2004 tentang Penghapusan Kekerasan Dalam Rumah Tangga. Undang-undang yang diharapkan dapat memberikan jaminan bagi perlindungan istri dalam keluarga ini ternyata menimbulkan persoalan tersendiri. Di satu sisi ada perlindungan terhadap istri yang diharapkan tidak akan ada kekerasan, termasuk kekerasan seksual yang menimpa dirinya. ${ }^{17}$ Namun di sisi lain, ia mengalami problem kalau harus melaporkan suaminya kepada aparat penegak hukum. ${ }^{18}$ Ketika itu dia dihadapkan kepada kondisi yang sulit, apakah ia akan mentolerir perlakuan buruk suami agar perkawinannya tidak hancur, ataukah akan melaporkan suaminya agar dipenjara, yang berarti ia kehilangan suaminya. Dalam pasal 46 UU PKDRT diatur mengenai sanksi pidana terhadap orang (suami atau istri) yang melakukan kekerasan seksual alam rumah tangga dengan hukuman pidana penjara paling lama 12 tahun atau denda paling banyak 36 juta rupiah. Ini berarti kalau hukuman pidana maksimal yang diterapkan atau hukuman di atas 5 tahun penjara, maka istri berhak menggugat cerai suaminya. Sebaliknya, suami yang dilaporkan ke penegak hukum oleh istrinya, pasti akan sulit menerima kembali istrinya itu, sehingga penyelesaian yang paling mungkin adalah dengan perceraian. Batas-batas kekerasan seksual juga tidak didefinisikan secara jelas oleh undang-undang tersebut, oleh karenanya mengundang kesamaran dalam masyarakat. ${ }^{19} \mathrm{Na}-$ mun, ternyata penderitaan istri belum selesai dengan diundangkannya UU PKDRT. Sebab, Majelis Ulama Indonesia dalam Musyawarah Nasional ke 9 di Surabaya mengeluarkan fatwa yang bertentangan dengan undang-undang tersebut. Fatwa bernomor: 02/Munas-IX/MUI/2015 ini menolak kriminalisasi (pemidanaan) terhadap hubungan seksual suami-

${ }^{17}$ Pasal 5 Undang-Undang Nomor 23 tahun 2004 tentang Penghapusan Kekerasan Dalam Rumah Tangga (UU PKDRT) menyebutkan bahwa kekerasan seksual merupakan salah satu bentuk kekerasan dalam rumah tangga.

${ }^{18}$ Pasal 44 UU PKDRT menyebutkan bahwa tindah pidana kekerasan seksual sebagaimana dimaksud dalam 46 yang dilakukan oleh suami terhadap istri atau sebaliknya merupakan delik aduan. Ini berarti penegak hukum tidak dapat memproses perkaranya kalau tidak ada pihak yang mengadu.

${ }^{19}$ Undang-Undang ini hanya mendefinisikan kekerasan seksual dengan definisi yang sangat umum, sehingga pihak suami yang melakukan kekerasan seksual, atau pihak istri yang menjadi korban kekerasan seksual sulit menentukan batas-batas kekerasan dimaksud. Biasanya, istri baru terdorong melaporkan kekerasan seksual yang menimpa dirinya kalau kekerasan yang terjadi tergolong berat. Undang-Undang ini dalam pasal 8 hanya menyebutkan bahwa yang dimaksud dengan kekerasan seksual di sini adalah: (1) pemaksaan hubungan seksual yang dilakukan terhadap orang yang menetap dalam lingkup rumah tangga tersebut. (2) pemaksaan hubungan seksual terhadap salah seorang dalam lingkup rumah tangganya dengan orang lain untuk tujuan komersial dan/atau tujuan tertentu. istri sebagaimana diatur dalam UU PKDRT. ${ }^{20}$ Dalam rekomendasinya, fatwa ini merekomendasikan tiga hal, yaitu: (1) Pemerintah dan DPR harus mereviu ketentuan peraturan perundang-undangan untuk disesuaikan dengan fatwa ini. (2) Aparat penegak hukum harus memahami secara utuh bahwa pidana perkosaan tidak dapat diterapkan dalam hubungan seksual yang dilakukan suami istri. (3) Masyarakat perlu memahami etika hubungan suami istri untuk menjamin terwujudnya hubungan keluarga yang sakinah, mawaddah dan rahmah. Ini berarti, kalau fatwa ini dijadikan sebagai rujukan untuk merevisi undang-undang PKDRT tersebut, maka perlindungan terhadap istri akan berkurang cakupannya.

Fatwa Majelis Ulama Indonesia di atas pada dasarnya sejalan dengan pandangan Syekh Nawawi Banten. Ia menggarisbawahi role of game atau etika yang harus dijaga dalam melakukan hubungan seksual suami istri, seperti tidak melakukan anal seks, tidak melakukan hubungan saat menstruasi, ${ }^{21}$ berdoa sebelum berhubungan badan, ${ }^{22}$ dan motivasi memperoleh anak (bagi pasangan yang masih menginginkannya). ${ }^{23}$ Sebab, bagaimana pun aktifitas seks merupakan aktifitas ibadah kepada Allah, karenanya harus tetap memperhatikan moral. Ia juga menyarankan beberapa posisi seks yang sehat dan tidak menganjurkan beberapa posisi yang dipandang dapat mengganggu kesehatan, seperti seks sambil berdiri, miring dan istri berada di atas suami. ${ }^{24}$

${ }^{20} \mathrm{Fatwa}$ ini memuat lima diktum, yaitu: (1) pada dasarnya, relasi suami istri harus dibangun sebagai manifestasi dari cinta (mawaddah) dan kasih sayang (rahmah), dan pelaksanaan hubungan suami istri merupakan ibadah. (2) pasangan suami istri haram melaksanakan hubungan seksual dalam kondisi yang terlarang secara syar'i, yaitu: (a) istri dalam kondisi haid dan nifas (b) suami atau istri sedang berpuasa Ramadhan (c) suami atau istri sedang ihram (d) dengan cara liwath (anal sex) (e) dalam kondisi sakit yang tidak memungkinkan untuk melakukan hubungan suami istri. (3) Suami wajib menjalin interaksi dengan istri secara ma'ruf (mu'asyarah bil ma'ruf) dan karenanya suami tidak boleh memaksa hubungan seksual kepada istri, dan istri wajib taat kepada suami sepanjang tidak untuk perbuatan maksiat, karenanya istri tidak boleh menolak ajakan suami untuk melakukan hubungan seksual kecuali dalam kondisi yang terlarang secara syar'i. (4) hubungan seksual antara suami dan istri dalam situasi terpaksa adalah khilaful aula (tidak sesuai dengan yang utama), tetapi tidak dapat dikategorikan sebagai perkosaan. (5) Kriminalisasi hubungan suami istri bertentangan dengan hukum Islam.

${ }^{21}$ Larangan berhubungan badan dengan istri pada masa haid berlaku sampai istri selesai dari haidnya dan telah selesai mandi. Sebelum selesai mandi, larangan tersebut tetap berlaku. Pendapat Syekh Nawawi Banten ini sejalan dengan pendapat yang disepakati oleh Imam Malik, al-Auza'i, as-Sauri dan asy-Syafi' 'i, dan berbeda dengan pendapat Imam Abu Hanifah yang menyatakan kalau masa suci dari haid tersebut kurang dari sepuluh hari, maka suami tidak boleh menggaulinya, tetapi jika sepuluh hari atau lebih, maka suami boleh menggaulinya, meskipun istri belum mandi.(Marah Labid, juz 1,76).

${ }^{22}$ Syekh Nawawi banten, Salalim al-Fuaala' Syara 'ala Manumah Hidayah al-Azkiya' ia ariq al-Auliya', (Demak: Penerbit Pesantren Pilang Wetan, t.th.), 103.

${ }^{23}$ Syekh Nawawi Banten, Mara Labid, juz 1, 78.

${ }^{24}$ Syekh Nawawi Banten, Salalim, 103-104. 
Suwarjin | Kekerasan Seksual Terhadap Perempuan 97

\section{Distorsi Pemahaman tentang Hak Seksual Perempuan}

Perempuan, sebagaimana laki-laki adalah mahluk yang dimuliakan Allah di atas mahluk lain. Islam menghargai perempuan sebagaimana menghargai laki-laki. Islam juga memberinya hak dan kewajiban secara seimbang dengan laki-laki. Karena itu hubungan suami-istri adalah hubungan kemitraan, bukan hubungan kekuasaan. ${ }^{25}$ Islam tidak membedakan kemuliaan manusia berdasarkan jenis kelamin tertentu. ${ }^{26}$ Dalam Alquran surat an-Nahl ayat 97 dinyatakan: "Barangsiapa yang mengerjakan amal saleh, baik laki-laki maupun perempuan dalam keadaan beriman, maka sesungguhnya akan Kami berikan kepadanya kehidupan yang baik dan sesungguhnya akan Kami beri balasan kepada mereka dengan pahala yang lebih baik dari apa yang telah mereka kerjakan." Ayat-ayat serupa ini banyak terdapat dalam Alquran, yang intinya menempatkan perempuan dalam posisi setara dengan laki-laki. Alquran lebih jauh menekankan pada setiap suami untuk mempergauli perempuan secara baik. Dalam surat anNisa' ayat 19 Allah menegaskan:”... dan bergaullah dengan mereka (para istri) secara patut."

Di dalam hadis Nabi terdapat banyak informasi tentang penghormatan Nabi kepada kaum perempuan. Pada kesempatan haji Wada' Nabi mengingatkan kepada umatnya akan pentingnya menghormati perempuan, ${ }^{27}$ sebagaimana pentingnya menjaga shalat. Dalam hadis lain, diriwayatkan Nabi sangat menghormati suami yang menghargai istrinya dan memperlakukannya secara baik. Beliau menyatakan:" Yang terbaik di antara kalian adalah yang paling baik perlakuannya kepada istri, dan aku adalah orang yang paling baik memperlakukan istri. ${ }^{28}$

Apa yang dilakukan oleh Nabi terhadap perempuan merupakan revolusi besar terhadap perempuan di berbagai belahan bumi dan di bawah berbagai peradaban kala itu. Seperti diketahui, bahwa sebelum Muhammad diangkat menjadi Rasul, nasib perempuan sangat menyedihkan. Ia diperlakukan secara diskriminatif dan dirampas hak-haknya.

Jika kita membuka lembaran-lembaran kitab fikih klasik, kita akan mendapati distorsi pemahaman yang sangat menyedihkan tentang hak seksual

${ }^{25}$ Husein Muhammad, Islam Agama Ramah Perempuan Pembelaan Kiai Pesantren, (Yogyakarta: LkiS, 2007), h. xxxiii.

${ }^{26}$ Siti Musdah Mulia, Islam dan Inspirasi Kesetaraan Gender, (Yogyakarta: Kibar Press, 2007), h. 12.

${ }^{27}$ Muhammad bin Yazid Abu Abdillah al-Qazwaini, Sunan Ibn Majah, (Beirut: Dar al-Fikr, t.th.), juz 1, h. 594.

${ }^{28}$ Muhammad bin Isa Abu Musa at-Tirmizi as-Sulami, al-Jami' as-Sahih Sunan at-Tirmizi, (Beirut: Dar Ihya' at-Turas al-'Arabiy, t.th.), juz 5, h. 709. istri. Dalam persoalan seksual, istri diposisikan sebagai obyek seks belaka. Ia seolah tidak memiliki hak untuk menikmati orgasme seksual. Perampasan hak seksual istri ini terjadi secara massif di dalam kitab-kitab fikih klasik. Celakanya, hal ini dicarikan legitimasi dari teks-teks hadis yang memberi kesan bahwa istri memang tidak berhak atas fantasi seksual yang diinginkannya. Dalam kitab Qurrah al-'Uyun, karya Sayid Maulana at-Tihami dikutip hadis Nabi yang menyatakan bahwa istri tidak boleh menunda hak suami menikmati kemolekan tubuhnya. "Allah melaknat al-musawwifat, ditanyakan: "Apa al-musawwifat itu?" Rasul menjawab: "Istri yang diajak suaminya ke tempat tidur lalu ia menundaa-nunda dan tidak mau melayani sampai suaminya tertidur." ${ }^{29}$

Di Indonesia, kekerasan seksual terhadap istri masih sering terjadi. Hal ini antara lain disebabkan oleh pemahaman yang negatif tentang hak seksual istri. Membicarakan hak seksual istri masih dianggap tabu oleh sebagian besar masyarakat Indonesia. Terlebih, secara ekonomi, mayoritas istri di perdesaan masih sangat tergantung kepada suami sebagai kepala keluarga. Ini menjadikan hak-hak istri terkait seks sering terabaikan, bahkan oleh istri itu sendiri. Para istri sangat jarang memikirkan hak-hak seksualnya. Yang lebih parah lagi, para istri sering memperoleh perlakuan semena-mena saat berhubungan seks dengan suami.

\section{Perlu Rekonstruksi}

Islam menempatkan hubungan seksual dalam posisi terhormat. Sebagai tujuan utama pernikahan, seks dipandang bernilai ibadah. ${ }^{30}$ Islam sangat menghormati perempuan. Dalam teks kitab suci digambarkan bahwa Islam sangat memuliakan perempuan. ${ }^{31}$ Selama ini di kalangan umat Islam Indonesia ada anggapan bahwa kitab kuning menjadi biang dari pelemahan perempuan di hadapan lakilaki. Kitab-kitab tersebut menempatkan perempuan sebagai warga kelas dua atau subordinat laki-laki. Pada batas tertentu anggapan tersebut mungkin benar, karena kitab-kitab tersebut disusun dalam situasi di mana perempuan terkungkung oleh budaya patriarki. Jadi sebetulnya, budaya patriarki-lah yang menjadi faktor utama pelemahan peran dan

\footnotetext{
${ }^{29}$ Asy-Syekh al-Imam Abu Muhammad Maulana at-Tihami, Syarh Qurrah al-'Uyun, Surabaya: Dar al-'Ilm, t.th.), h. 20.

${ }^{30}$ Taqiy ad-Din Abi Bakr bin Muhammad al-Husaini al-Hisni ad-Dimasyqiy asy-Syafi'iy, Kifayah al-Akhyar fi Hall Ghayah al-Ikhtishar, (Bandung: al-Ma'arif, t.th.), juz 1, h. 489 .

${ }^{31}$ Musdah Mulia, Islam dan Inspirasi..., h. 17.
} 
Suwarjin I Kekerasan Seksual Terhadap Perempuan

posisi perempuan di ruang domestik maupun ruang publik. Namun, budaya patriarki tersebut kemudian membawa serta agama kedalamnya.

Asghar Ali Engineer secara tegas mengatakan bahwa agama bukanlah faktor utama bagi terbentuknya konstruksi sosial yang melemahkan peran dan posisi perempuan. Pada kenyataannya budaya patriarki-lah yang menjadi faktor utamanya. Ini bukan berarti agama tidak berperan sama sekali, namun perannya sebatas sebagai penguat budaya patriarki tersebut. Sebab, pada masyarakat agamis, seperti Indonesia ini, penggunaan doktrin-doktrin agama dipandang sangat efektif dan mudah diterima. Suatu konstruksi budaya yang bisa jadi tidak humanis dan tidak mencerminkan prinsip keadilan, bisa saja diterima dan diyakini sebagai suatu kebenaran, apabila memperoleh justifikasi dari agama. Sebut saja misalnya, kebiasaan suami memaksakan hasrat seksual kepada istri, dipandang sebagai otoritas laki-laki atas perempuan, yang dalam praktiknya dilakukan tanpa memikirkan kondisi fisik dan psikis istri. Kebiasaan ini diterima secara luas oleh masyarakat Muslim Indonesia karena diperkuat dengan argumen dari teks-teks suci.

Untuk mengatasi problem kekerasan seksual tersebut perlu dilakukan rekonstruksi. Setidaknya ada dua cara yang dapat ditempuh dalam melakukan rekonstruksi pemahaman hak seksual istri ini. Pertama, dengan kembali kepada sumber utama ajaran Islam, yaitu Alquran dan Hadis. Kembali kepada Alquran dan Hadis yang dimaksud di sini adalah dengan melakukan pembacaan ulang kedua sumber ajaran Islam tersebut dengan menggunakan pendekatan ilmu-ilmu modern. Kita bisa menggunakan berbagai pendekatan dalam membaca kedua sumber tersebut, seperti pendekatan historis, pendekatan Hak Asasi Manusia (HAM), antropologi, hermeneutika atau lainnya. Dengan pendekatan-pendekatan tersebut akan diperoleh pemahaman baru yang lebih produktif dan sesuai kemaslahatan kekinian. Kedua, dengan mengkonstruksi budaya baru yang lebih humanis dan berkeadaban. Untuk mengkonstruksi budaya diperlukan rekayasa sosial. Melalui rekayasa sosial budaya yang kontra produktif dan bertentangan dengan nilai-nilai kemanusiaan universal dapat diperbaiki. Misalnya budaya patriarki yang menjadi penyebab timbulnya pelemahan terhadap perempuan dapat direkayasa menjadi budaya kemitraan, di mana laki-laki diposisikan sebagai superior-inferior, tetapi sebagai mitra yang memiliki kedudukan setara.

\section{Kesimpulan}

Kekerasan seksual pada istri lahir dari budaya patriarki yang kemudian dijustifikasi melalui teksteks suci. Selama berabad-abad lamanya kekerasan seksual pada istri terhampar di medan budaya dan agama. Seolah agama melegalkan kekerasan seksual, sebagaimana budaya melegalkannya. Padahal, agama sebagai doktrin sarat dengan nilai-nilai ketuhanan dan kemanusiaan. Tuhan, sebagai pencipta laki-laki, tentu tidak menghendaki terjadinya perbedaan derajat laki-laki dan perempuan. Kalau dalam kitab-kitab fikih terdapat kesan bahwa kedudukan laki-laki lebih tinggi dari perempuan, maka sesungguhnya itu berangkat dari pemahaman yang keliru terhadap sumber ajaran Islam. Kiranya perlu dilakukan pembacaan yang lebih produktif, baik terhadap teks suci maupun teks keagamaan lainnya agar diperoleh pemahaman yang sesuai dengan yang dikehendaki oleh Sang Pemilik Hukum, yaitu Allah SWT. ini penting dilakukan, agar Islam tidak selalu menjadi pihak yang selalu dipersalahkan, seolah Islam bertentangan dengan kemanusiaan.

\section{Daftar Pustaka}

Abdul Munir Mulkhan, Perspektif Sosiologis Kekerasan Fikih terhadap Perempuan, dalam, S. Edi Santoso, Islam dan Konstruksi Seksualitas, Yogyakarta: Pustaka Pelajar, 2002.

Asy-Syekh al-Imam Abu Muhammad Maulana at-Tihami, Qurrah al-'Uyun Berbulan Madu Menurut Ajaran Rasulullah, terj. Asy'ari Mahmud, t.t: t.p, t.th.

Asy-Syekh al-Imam Abu Muhammad Maulana atTihami, Syarh Qurrah al-'Uyun, Surabaya: Dar al-'Ilm, t.th.

Asghar Ali Engineer, Pembebasan Perempuan, terj. Agus Nuryatno, Yogyakarta: LkiS, 2007.

Husein Muhammad, Islam Agama Ramah Perempuan Pembelaan Kiai Pesantren, Yogyakarta: LkiS, 2007.

Ibn Qayyim al-Jauziyah, I'lam al-Muwaqqi' in 'an Rabb al-'Alamin, http//www.al-islam.com, jilid 3 .

Muhammad bin Isma'il bin Ibrahim bin al-Mughirah al-Bukhari, Shahih al-Bukhari, t.t.: Dar Thauq an-Najah, 1422 H. juz 7

Muhammad bin Yazid Abu Abdillah al-Qazwaini, Sunan Ibn Majah, Beirut: Dar al-Fikr, t.th., juz 1.

Muhammad bin Isa Abu Musa at-Tirmizi as-Sulami, al-Jami' as-Sahih Sunan at-Tirmizi, Beirut: Dar Ihya' at-Turas al-'Arabiy, t.th. 
Suwarjin | Kekerasan Seksual Terhadap Perempuan

Siti Musdah Mulia, Islam dan Inspirasi Kesetaraan Gender, Yogyakarta: Kibar Press, 2007.

Syekh Nawawi Banten, Mara Labid li Kasyf Ma'na alQur'an al-Majid, Bandung: Syirkah al-Ma'arif, t.th., juz 1
Taqiy ad-Din Abi Bakr bin Muhammad al-Husaini al-Hisni ad-Dimasyqiy asy-Syafi'iy, Kifayah alAkhyar fi Hall Ghayah al-Ikhtishar, Bandung: al-Ma'arif, t.th., juz 1 
